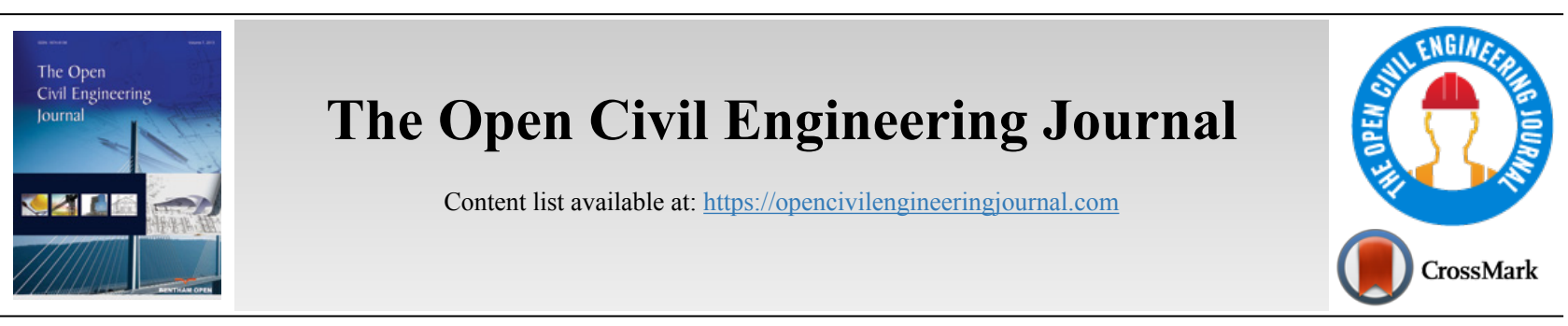

RESEARCH ARTICLE

\title{
Development of a Multiple Coil Magneto-Rheological Smart Damper to Improve the Seismic Resilience of Building Structures
}

\author{
Daniel Cruze ${ }^{1(D)}$, Hemalatha Gladston ${ }^{1(D)}$, Ehsan Noroozinejad Farsangi ${ }^{2, *(D)}$, Sarala Loganathan ${ }^{1(D)}$, Tensing \\ Dharmaraj $^{1(D)}$ and Sundar M. Solomon ${ }^{3}$
}

${ }^{1}$ Department of Civil Engineering, Karunya Institute of Technology and Sciences, Coimbatore, India

${ }^{2}$ Faculty of Civil and Surveying Engineering, Graduate University of Advanced Technology, Kerman, Iran

${ }^{3}$ Pandit Deendayal Petroleum University, Gandhinagar, India

\begin{abstract}
:
Introduction:

The incremental research progress on Magneto-Rheological (MR) damper and its response motivated many researchers and engineers to focus on this topic in the last decade.

Methods:

MR damper is classified as a semi-active vibration controlling device owing to its mechanical simplicity, low power usage, large response reduction, perfect damping mechanism, good stability, quick reaction time and robust interface.

Results:

In the current investigation, experimental studies were performed for the design, development, and testing of a new type of MR damper. A proposed approach was adopted for the magnetic generation using multi-coils to produce more shear force in the flow gap. The study investigates time history responses of the proposed system under an array of strong ground motions at both element and structure levels. Numerical hybrid simulation using OpenSees has also been carried out on a building structure to show the effectiveness of the new device.

\section{Conclusion:}

The performance of the investigated structure equipped with the proposed system indicates a large reduction in displacement and an increase in damping force under major seismic events.
\end{abstract}

Keywords: MR damper, Nonlinear control, Semi-active, OpenSees, RC frame, Seismic resilience, Response control, Numerical hybrid simulation.

\begin{tabular}{|l|l|l|r} 
Article History & Received: January 21, 2020 & Revised: March 09, 2020 & Accepted: March 25, 2020
\end{tabular}

\section{INTRODUCTION}

In recent years, many researchers have focused on adding control systems in structures/infrastructure to monitor and minimize earthquake vibrations. Particularly, it has been proved by researchers that Magneto-Rheological (MR) dampers have more advantages over conventional vibration control devices. Notably, simple mechanical design, less power, more damping force, and better stability are added advantages. Most of the MR dampers are working based on the Bouc-Wen hysteretic model which controls vibration in build-

\footnotetext{
* Address correspondence to this author at the Faculty of Civil and Surveying Engineering, Graduate University of Advanced Technology, Kerman, Iran; Tel: +98-34-3162-3383; E-mail: noroozinejad@kgut.ac.ir
}

ings and bridges. In the last couple of years, researchers were implementing various mathematical models and algorithms to prove the superior performance of MR dampers for seismic application. However, the implementation of these devices in building structures was not attained to date due to the high cost of MR Dampers and MR Fluid [1 - 9]. MR fluids also called controllable fluids are classified as smart materials category composed of nano to micron size magnetic particles disseminated in a liquid carrier of hydrocarbon oils. MR fluids respond in a unique manner to the applied magnetic field, by changing their rheology under various magnetic fields [10 14]. In detail, particularly in the absence of a magnetic field, these MR fluids normally act as conventional oil, while in the presence of the magnetic field, magnetic iron particles present 
in the fluid align themselves along magnetic flux lines. The reaction time of the fluid is in milliseconds. Furthermore, the MR fluids possess a steady hysteretic characteristic, high yield stress, and variations in viscosity and temperature range [15 21]. However, the cost of MR fluids is very high [22 - 24]. The semi-active eddy current pendulum tuned mass damper with variable frequency and damping using a Linear-QuadraticGaussian (LQG)-based control algorithm can be used as a vibration resistance of structures for both seismic and wind forces $[25,26]$. MR damper works in three modes of operation: namely squeeze, shear and valve modes. In the design aspects of MR Dampers, many novel ideas were contributed by researchers. Notably, the variation in the outer cylinder, piston diameter, annular gap, and magnetic circuit geometry makes such dampers to perform in a superior way. Therefore, a welldetailed investigation should be performed before fabricating these devices [27 - 31]. Conventional vibration control devices have many limitations as they are compromising the application as passive dampers. Whereas the MR devices are belonging to active and semi-active categories. Therefore, the control system has less power requirement and change its response when needed, depending on the design and demand [32].

In the current study, an innovative MR damper with 9 multiple coils is designed, fabricated and tested under several strong ground motions. The advantage of using the toothing system in the piston configuration is the alternate polarities in the magnetic field which strengthen the fluid through two adjacent cores in the piston. Additionally, numerical investigations using OpenSees software were carried out for seismic mitigation of the building structures. OpenSees is well recognized as one of the best nonlinear platforms for earthquake engineering simulation applications. Various researches on the performance assessment of RC frames with various control devices under seismic excitations have been done using this software [33, 34].

\section{THE PROPOSED DEVICE}

\subsection{MR Fluid}

The Lord MRF-132 DG is a commercially available
Magneto-Rheological fluid generally used for controlling devices. It is a dark gray liquid with high density. It is composed of a suspension of magnetic iron particles in hydrocarbon-based oil. Additionally, it is mixed with additives to reduce sedimentation. The viscosity of the fluid is about $0.112 \mathrm{~Pa} / \mathrm{s}$ and varies in the presence and absence of a magnetic field. The rheological behavior of the fluid is instant and reversible. The fast reaction time is an added advantage of the fluid. The flashpoint of the fluid is above 150-degree Celsius. The technical data such as yield stress, shear stress and shear rate of the fluid are given in the material safety data sheet (MSDS) of the fluid [35].

\subsection{MR Damper}

In general, the damping force generated in the MR damper is due to the result of viscous friction when the magnetic field is applied. MR fluid is endorsed inside the cylinder with an annular gap of $1 \mathrm{~mm}$. The viscosity of the fluid varies according to the magnetic field created by the coil [36 - 38]. Conventional MR damper has a maximum of 3 piston poles and 3 coils, whereas in the proposed MR damper 9 coils and 10 piston poles with a uniform distance of $10 \mathrm{~mm}$ and a depth of $20 \mathrm{~mm}$ were fabricated to produce more shear forces. The thickness of the cylinder was $5 \mathrm{~mm}$. Generally, increasing the number of flow gaps by having more piston poles results in more shear forces in the sides of the piston which is depicted in Fig. (1). A maximum damping force of $15 \mathrm{kN}$ can be generated by the proposed MR damper. As per the design, the electromagnetic circuit can provide more flux lines in the flow gaps within milliseconds as shown in Fig. (2). For producing $15 \mathrm{kN}$ damping force, 9 multiple coils should be modeled. The wires from the coils were connected to the DC power supply, and as a result, the magnetic field was generated and yield stress in the MR fluid appeared. The advantage of using the toothing system in the piston configuration is the alternate polarities in the magnetic field strengthen the fluid through two adjacent cores in the piston. Whereas in the conventional single coil it is absent. The proposed damper has a payload of $13.2 \mathrm{~kg}$. The coil properties are given in Table 1. As per the design, the proposed damper was fabricated and shown in Fig. (3). The electromagnetic coil is wounded on a light-duty lathe.

Table 1. Coil properties.

\begin{tabular}{|c|c|}
\hline Parameter & Value \\
\hline Inductance & $83100 \mathrm{microH}$ \\
\hline Former Diameter & $60 \mathrm{~mm}$ \\
\hline Winding Length & $100 \mathrm{~mm}$ \\
\hline Wire Diameter & $0.61 \mathrm{~mm}$ \\
\hline Coil turns & 1638 \\
\hline Coil Thickness & $20 \mathrm{~mm}$ \\
\hline Coil Resistance & $20.727 \mathrm{Ohm}$ \\
\hline Length of wire without leads & $346.142 \mathrm{~m}$ \\
\hline Weight of wire & $900.313 \mathrm{~g}$ \\
\hline Number of layers & 9 \\
\hline Wire Diameter with insulation & $0.6649 \mathrm{~mm}$ \\
\hline
\end{tabular}




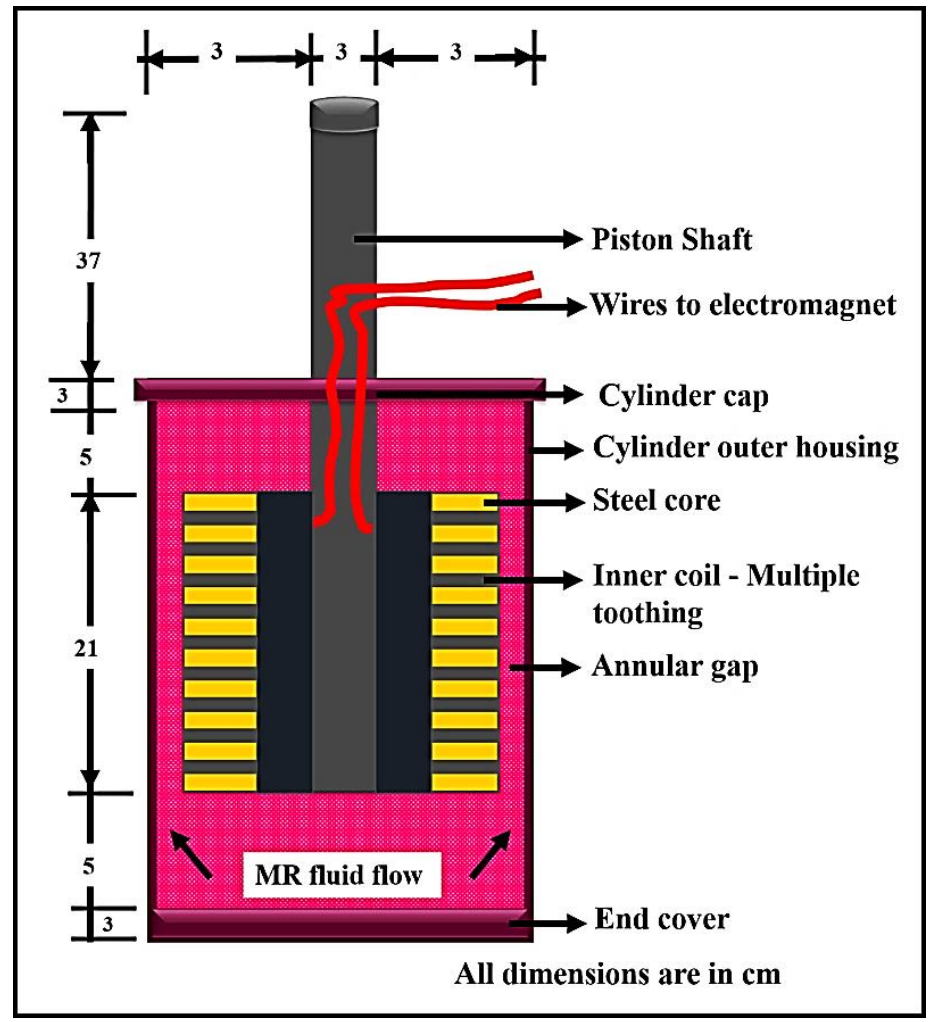

Fig. (1). Schematic representation of the proposed MR Damper.

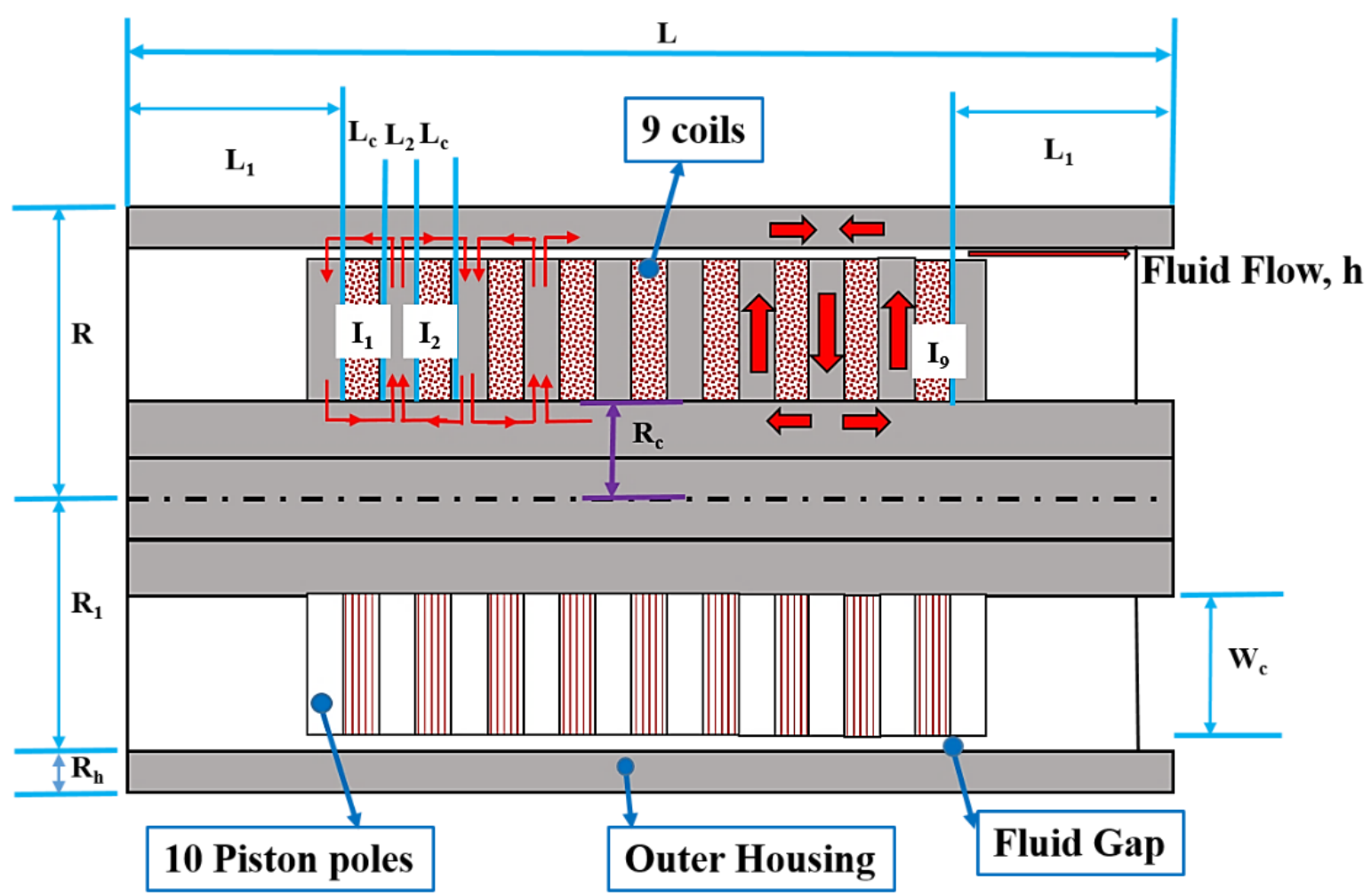

Fig. (2). Flux direction and magnetic circuit in the proposed MR Damper. 


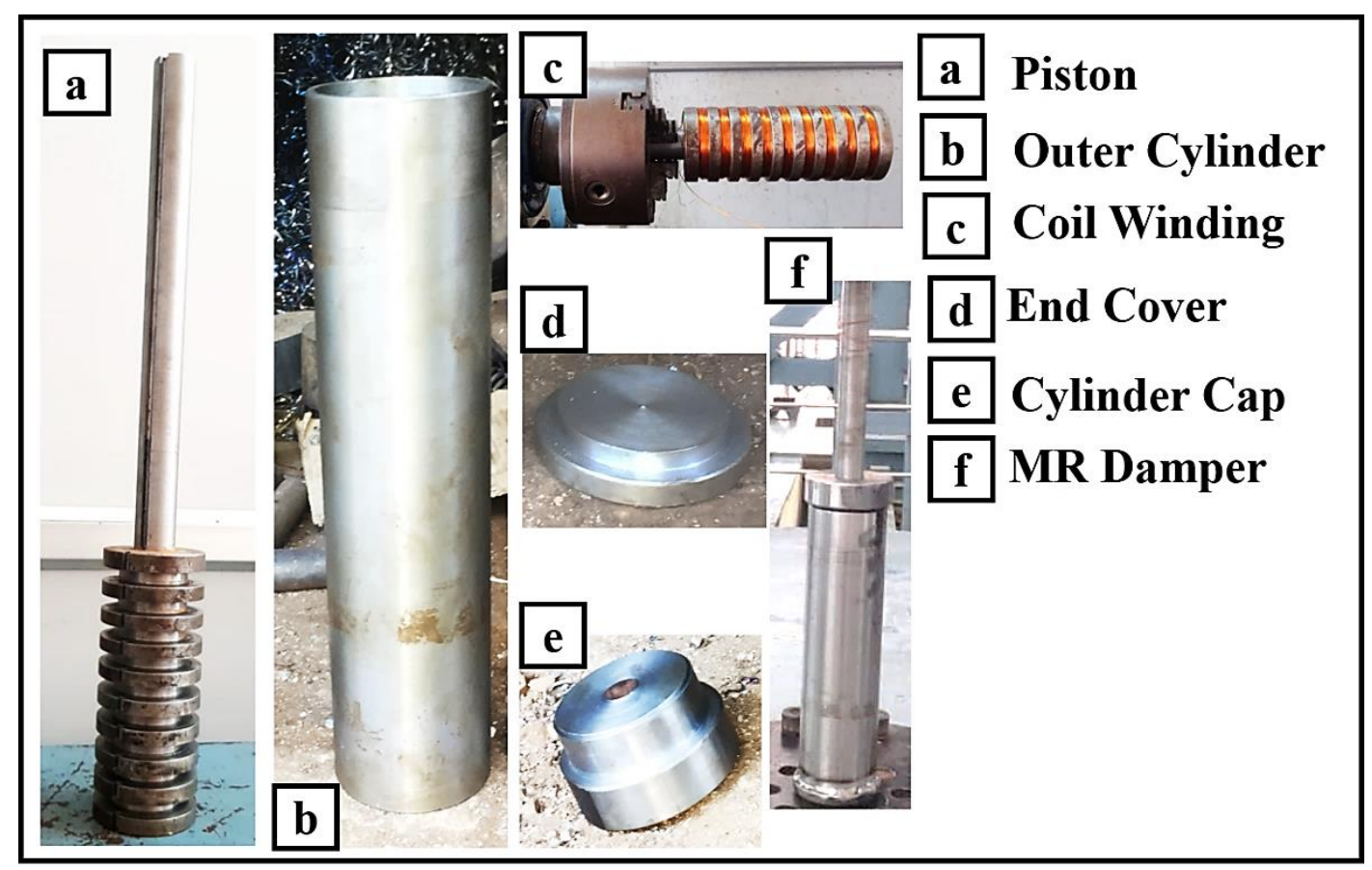

Fig. (3). Components of the proposed MR damper.

\subsection{Principle and Magnetic Circuit of the Proposed MR Damper}

The scheme of flux direction and magnetic circuit of the proposed damper is depicted in Fig. (2). The chambers in the device are filled with MR fluid. The accumulator is not provided at the bottom end of the chamber. When the piston moves, MR fluid flows through the annular gaps between chambers. The 9 coils are heat-resistant and electrically insulated. When the magnetic field applied, the field created around the piston head. Due to the effect of the current supply, the magnetic field direction in multiple coils creates maximum damping force. The magnetic flux lines are perpendicular to the flow direction and provide resistance to the flow. The proposed design can control a wide range through varying values and directions of current. The active volume of MR fluid is defined as the magnetic field passes the volume of fluid. Magnetic field and power required by coils should maintain the balance to optimize the circuit. Currents $\mathrm{I}_{1}, \mathrm{I}_{2}, \mathrm{I}_{3}, \mathrm{I}_{4}, \ldots$, and $\mathrm{I}_{9}$ were applied in the $1^{\text {st }}, 2^{\text {nd }}, 3^{\text {rd }}, 4^{\text {th }} \ldots$. and $9^{\text {th }}$-coil, respectively. When the magnetic flux density increases, the viscosity of the fluid resistance in the gaps also increases and will produce damping force as a result. The damper geometry is characterized by the length of piston head $L$, the thickness of outer housing $R_{h}$, the width of coil $W_{c}$, the radius of the cylinder $R$, the length of coil $L_{c}$, the radius of piston $R_{c}$, the magnetic field dependent force $F_{\tau}$, the friction force $F_{f}$, and the viscous force $F_{\eta}$. The total force is calculated as follows (Eq. 1):

$$
F=F_{\tau}+F_{\eta}+F_{f}
$$

The coils properties and the configuration of the new device are presented in Table $\mathbf{1}$ and Fig. (3).

\section{EXPERIMENTAL INVESTIGATIONS}

\subsection{Magnetic Flux Density Test}

To measure the magnetic flux density of the coil, a unique test setup was built in our lab as shown in Fig. (4). The \#. 23 standard wire gauge with a diameter of $0.61 \mathrm{~mm}$ was used in the experiment. Magnetic flux density was evaluated using the hall probe, at the current interval of $0.25 \mathrm{~A}$. A voltage of $8.5 \mathrm{~V}$ was set as a constant throughout the test. At the maximum current of 3A, 2.15 Tesla was observed in the coil as shown in Fig. (5).

\subsection{Time History Loading Test}

Damper assessment was carried out by time history loading approach under four different strong ground motions, (namely El Centro 1940, Northridge 1994, Petrolia 1992, and Loma Preita 1989) in the MTS 100 T UTM machine in Karunya Institute of Technology and Sciences, Coimbatore as shown in Fig. (6). $0 \mathrm{~A}$ and $3 \mathrm{~A}$ currents were kept in the power supply for the entire test. Top of the piston and the end cover were fixed with threaded fixtures. The earthquake event details are tabulated in Table 2. The resulted damping forces of the proposed MR damper are also obtained and presented in Table 3. The input of the MTS Machine was taken as a displacement response. Therefore, as shown in Figs. (7 and 8), acceleration time-histories were converted to displacement time-histories to perform the experiments. The PGA values used in this study were in the range of $0.276 \mathrm{~g}-0.662 \mathrm{~g}$. 


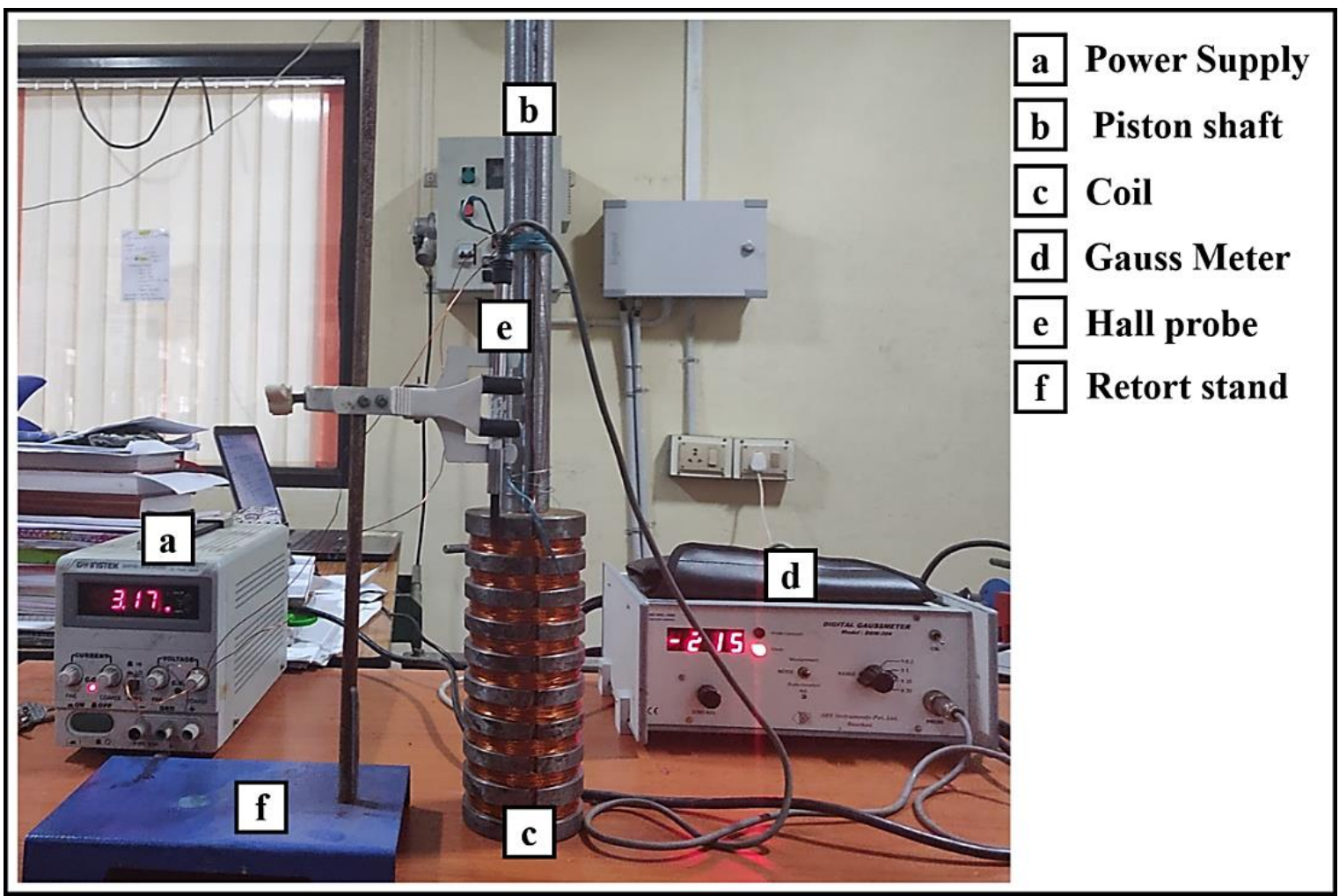

Fig. (4). Magnetic flux density test setup.

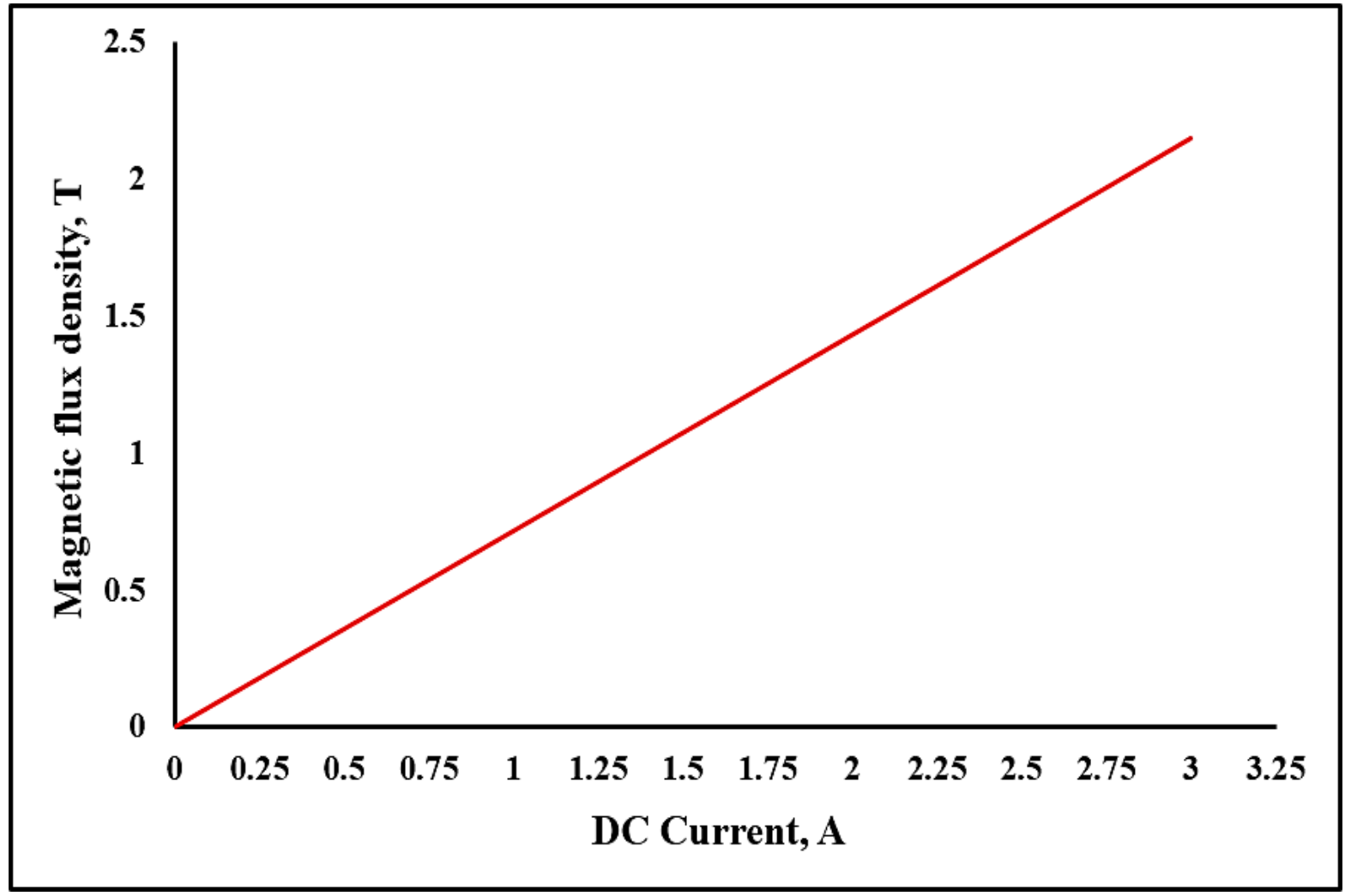

Fig. (5). Current vs. Magnetic flux density for the proposed damper. 


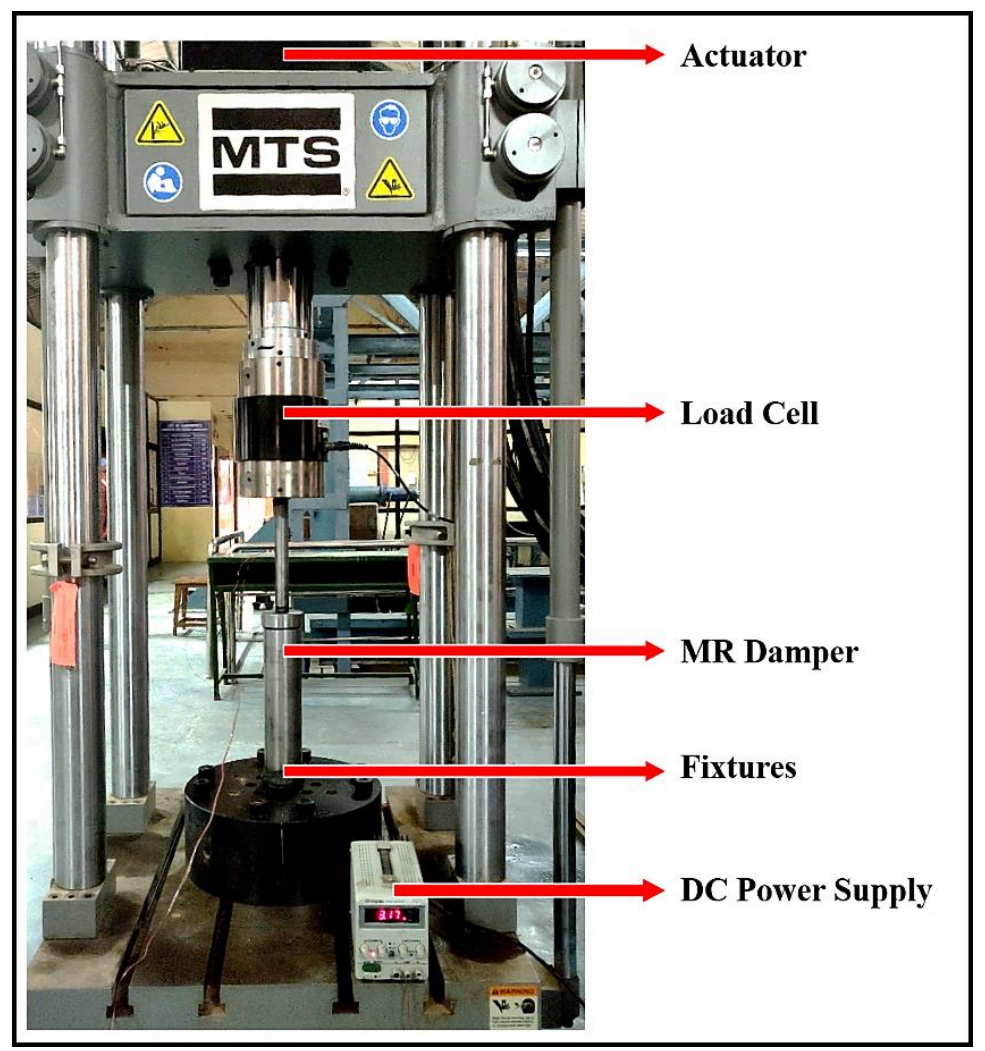

Fig. (6). The proposed MR damper in the MTS machine.

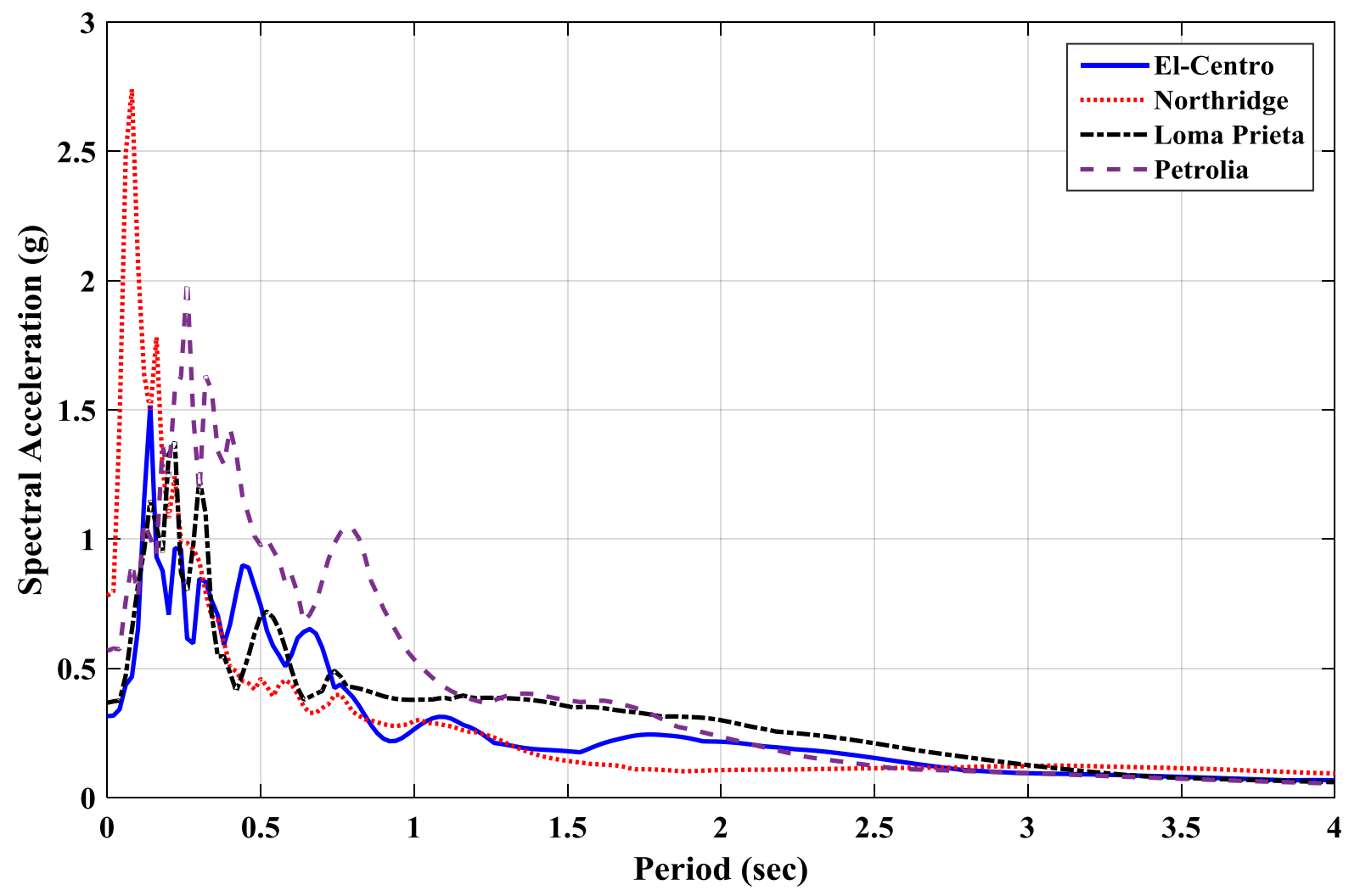

Fig. (7). Response spectra of the selected ground motions. 


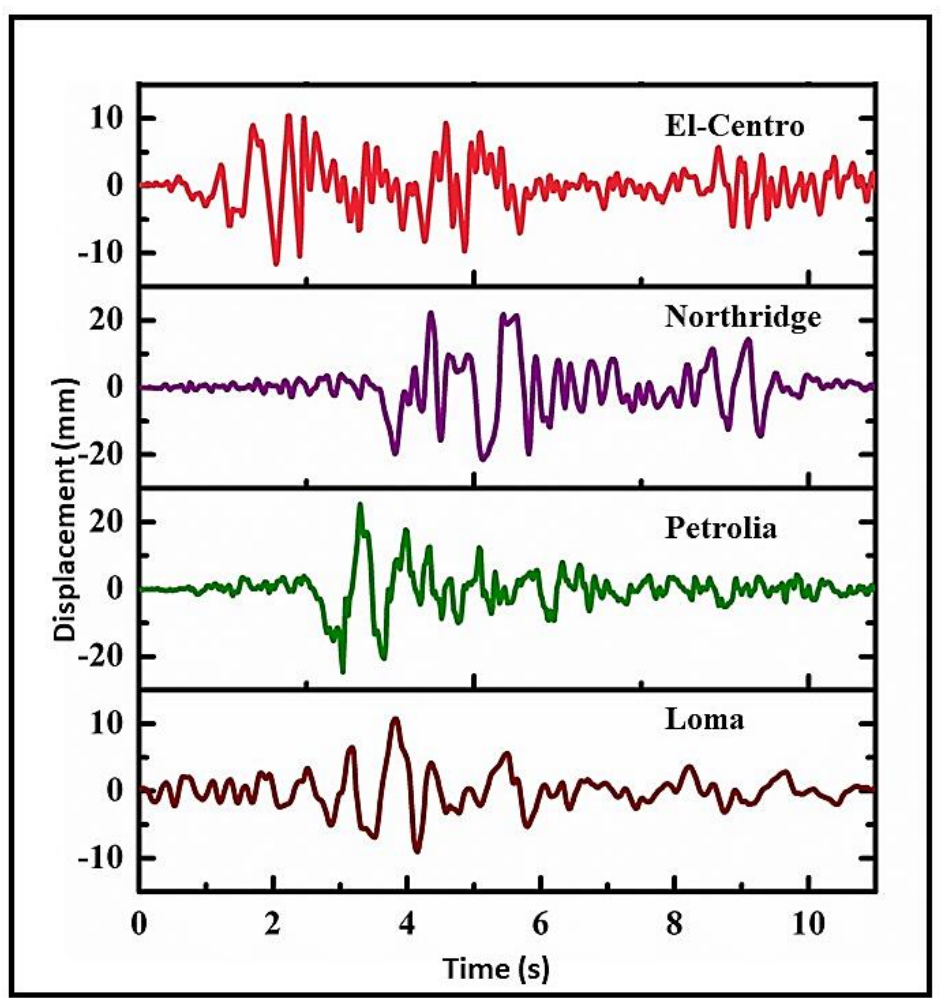

Fig. (8). Input displacement $v s$. time for the considered earthquakes.

Table 2. Details of the used earthquake events.

\begin{tabular}{|c|c|c|c|c|c|c|}
\hline Earthquake Event & Date and Year & Station & $\begin{array}{c}\text { Magnitude } \\
(\mathbf{M w})\end{array}$ & PGA (g) & Epicenter & $\begin{array}{c}\text { Maximum Input } \\
\text { Displacement (mm) }\end{array}$ \\
\hline El Centro & May 18, 1940 & $\begin{array}{c}\text { Imperial Valley- Southern } \\
\text { California }\end{array}$ & 6.9 & 0.321 & $32.733^{\circ} \mathrm{N} 115.5^{\circ} \mathrm{W}$ & 11.628 \\
\hline Northridge & January 17, 1994 & Newhall - La County Fire Station & 6.7 & 0.583 & $34.213^{\circ} \mathrm{N} 118.537^{\circ} \mathrm{W}$ & 22.251 \\
\hline Petrolia & April 25, 1992 & Cape Mendocino & 7.2 & 0.662 & $40.33^{\circ} \mathrm{N} 124.23^{\circ} \mathrm{W}$ & 25.289 \\
\hline Loma Prieta & October 17, 1989 & Oakland Outer Harbor Wharf & 6.9 & 0.276 & $37.04^{\circ} \mathrm{N} 121.88^{\circ} \mathrm{W}$ & 10.734 \\
\hline
\end{tabular}

Table 3. Experimental results (Element level).

\begin{tabular}{|c|c|c|c|c|c|c|c|}
\hline \multirow{2}{*}{ No. } & \multirow{2}{*}{ Earthquake } & \multicolumn{2}{|c|}{ Damping Force (kN) } & Damper Displacement (mm) & \% Increase in Damping Force & \% Reduction in Displacement \\
\cline { 3 - 8 } & & $0 \mathrm{~A}$ & $3 \mathrm{~A}$ & $0 \mathrm{~A}$ & $3 \mathrm{~A}$ & $0 \mathrm{~A}$ to 3A & $0 \mathrm{~A}$ to 3A \\
\hline 1 & El Centro & 1.18 & 13.08 & 11.59 & 9.17 & 1008.47 & 20.87 \\
\hline 2 & Northridge & 1.36 & 13.37 & 21.36 & 19.72 & 883.09 & 13.71 \\
\hline 3 & Petrolia & 1.43 & 12.86 & 19.85 & 17.085 & 799.30 & 14.95 \\
\hline 4 & Loma & 1.08 & 12.08 & 10.76 & 9.25 & 1018.52 & 14.15 \\
\hline- & Average & 1.26 & 12.85 & 15.89 & 13.81 & 919.84 & \\
\hline
\end{tabular}

\subsection{Hysteretic Responses}

To proceed with the hybrid simulations, experimental time step results produce stiffness of the MR Damper for different earthquakes under $0 \mathrm{~A}$ and $3 \mathrm{~A}$ currents. In the next step, these results are used as inputs for numerical simulation in OpenSees. Damping force for $0 \mathrm{~A}$ and $3 \mathrm{~A}$ for four earthquakes are shown in Fig. $(9$ a-d). The damping force $v s$. time for $0 \mathrm{~A}$ and $3 \mathrm{~A}$ are plotted in Fig. (10).

\section{NUMERICAL INVESTIGATION (HYBRID SIMU- LATION)}

Using OpenSees (Open System for Earthquake Engineering Simulation) software, a single-story RC frame equipped with the proposed system was considered to study the 
effectiveness of the new device at the structure's level [3943]. The basic geometry of the model is shown in Fig. (11). Beam and columns were modeled using a non linear beam-
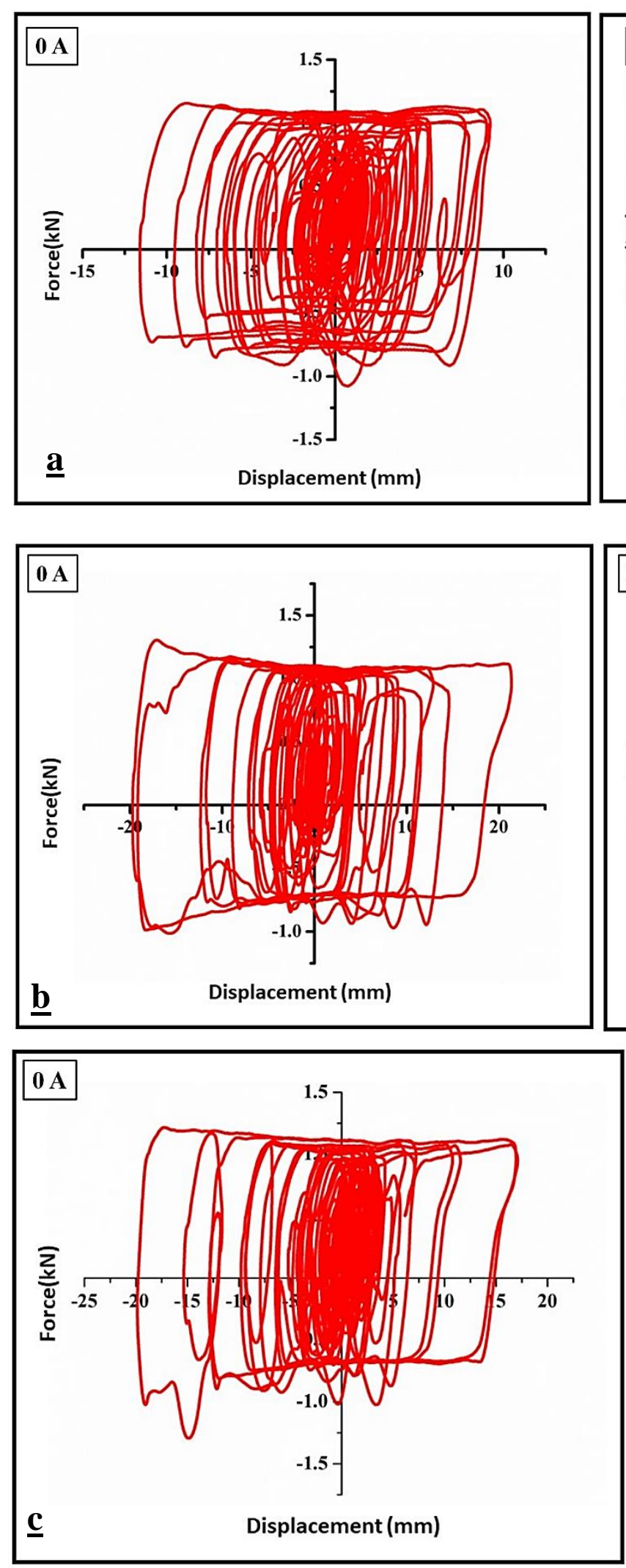

column element. To define the geometry of the proposed MR damper, two node-link elements were created diagonally and were used to link two nodes with an element. The element has $\mathrm{n}$ length and 6 degrees of freedom.
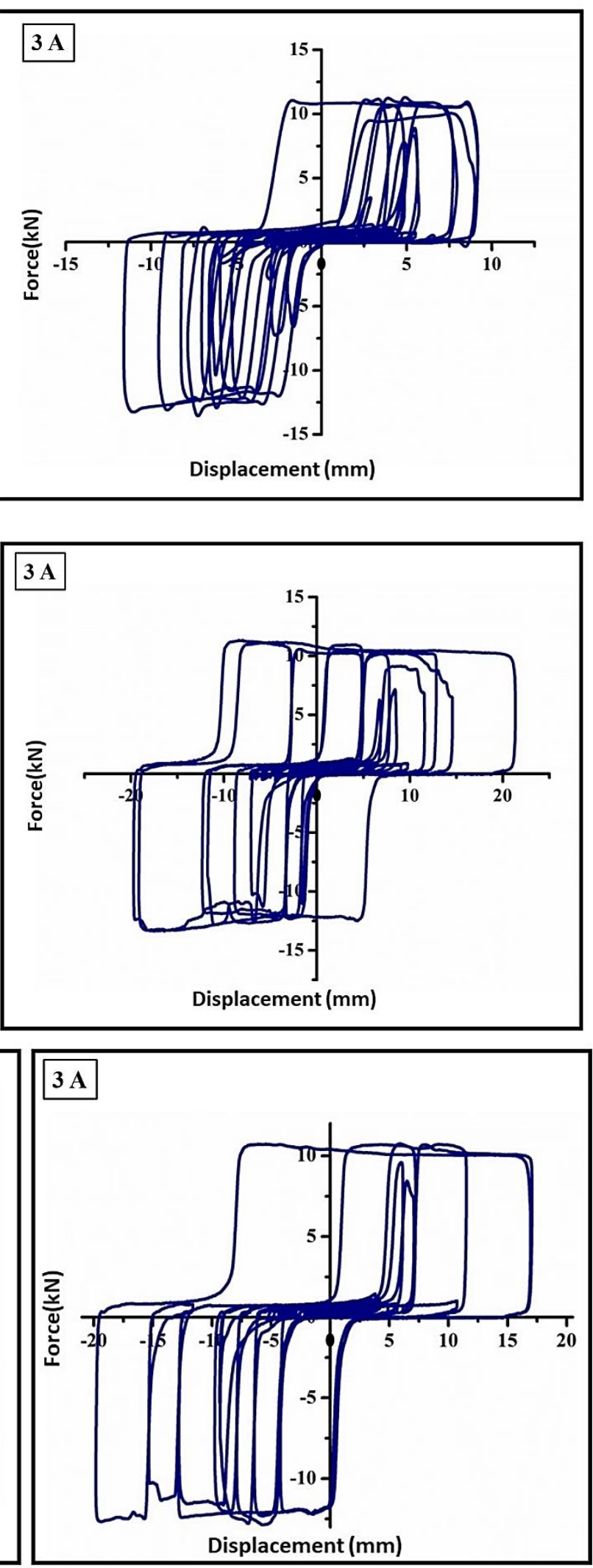

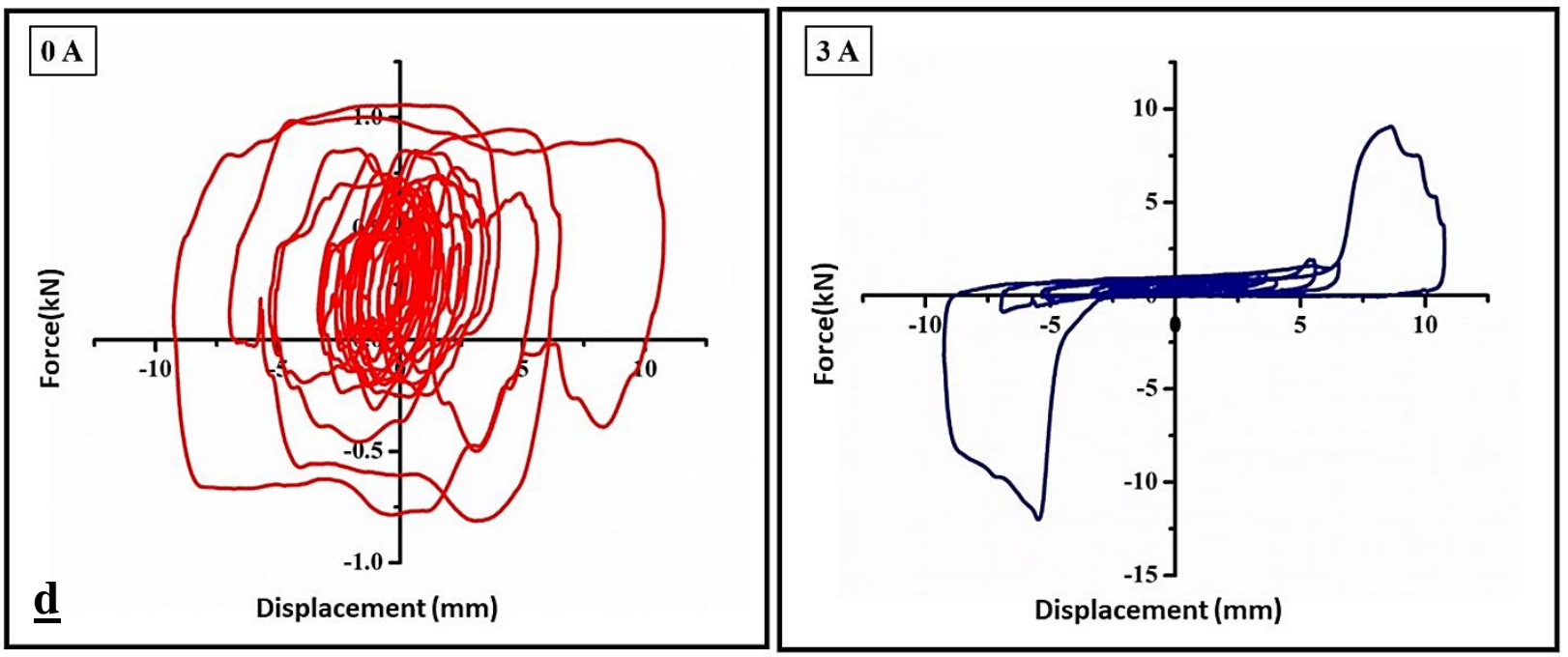

Fig. (9). Force-displacement responses of the proposed device a) El Centro; b) Northridge; c) Petrolia; d) Loma Prieta.

The input parameters are based on the Bouc-Wen material properties. This model has a nonlinear basis and the backbone differential equation has some mathematical parameters which should be defined and calibrated appropriately to give accurate results. These parameters are defined as; Alpha which is the ratio of post-yield stiffness to the initial elastic stiffness, $\mathrm{K}$ which is the stiffness at each time interval, and $\gamma$ and $\beta$ defined as the softening, hardening or quasi-linearity of hysteretic loop characteristics.
The single-story RC frame shown in Fig. (12) equipped with MR damper was subjected to four earthquakes time history records. The detailing of a frame was added to the material properties of the beam-column elements. The boundary conditions were numbered according to the behavior of elements. Kyrlow-Newton-Newmark integrator was used for time history analysis for various time steps. As a logical assumption, MR damper was kept diagonal throughout the analysis. The dimension and reinforcement details of the model are tabulated in Tables $\mathbf{4}$ and $\mathbf{5}$.
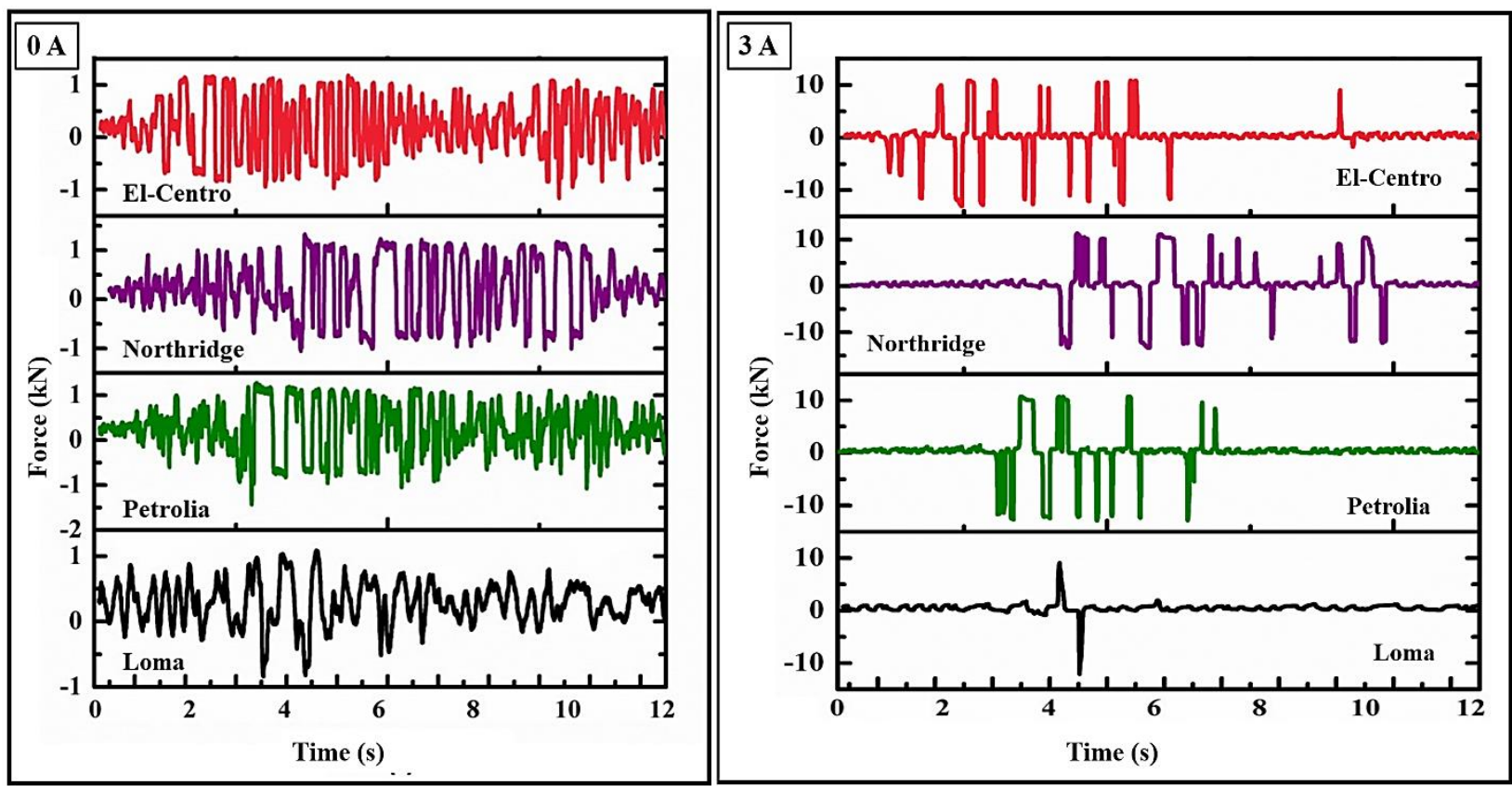

Fig. (10). Damping force $v s$. time under $0 \mathrm{~A}$ and $3 \mathrm{~A}$ currents for 4 earthquake events. 


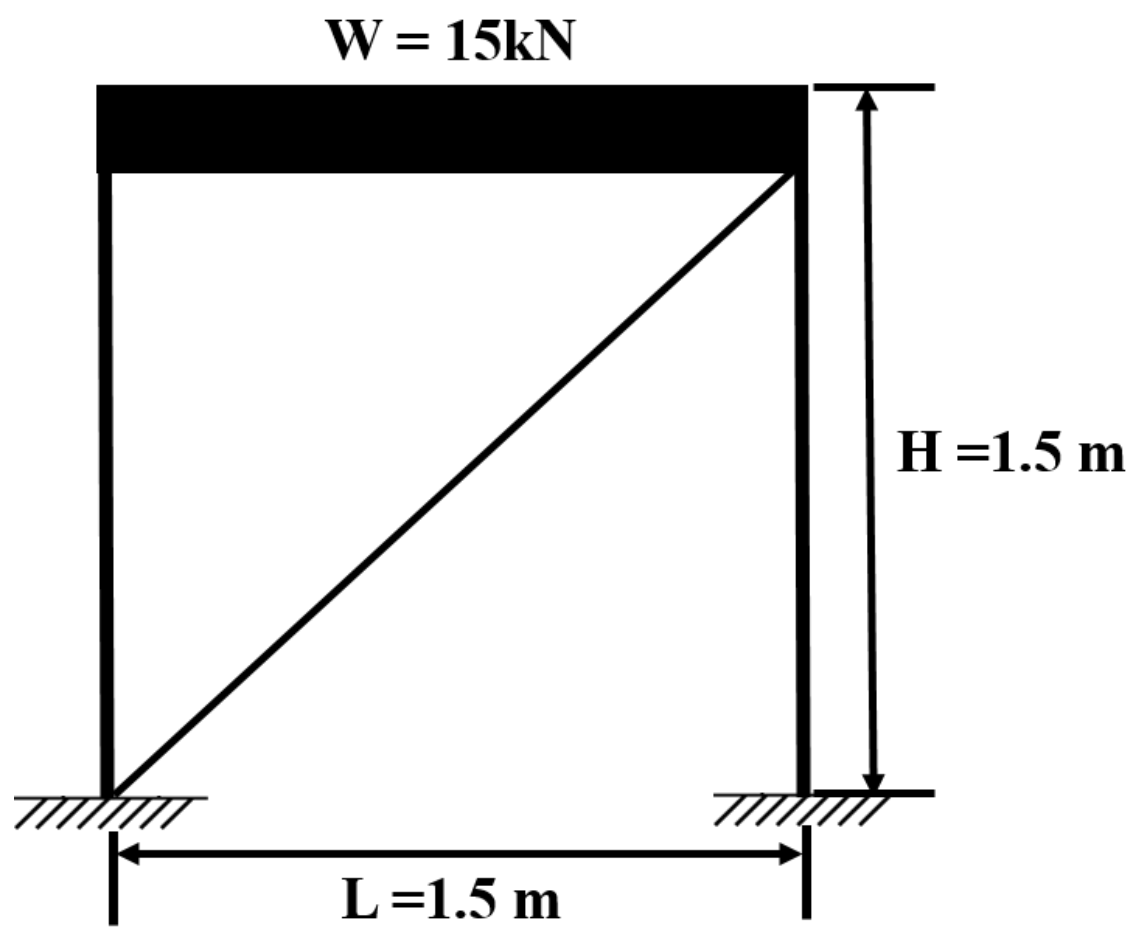

Fig. (11). Model geometry [39].

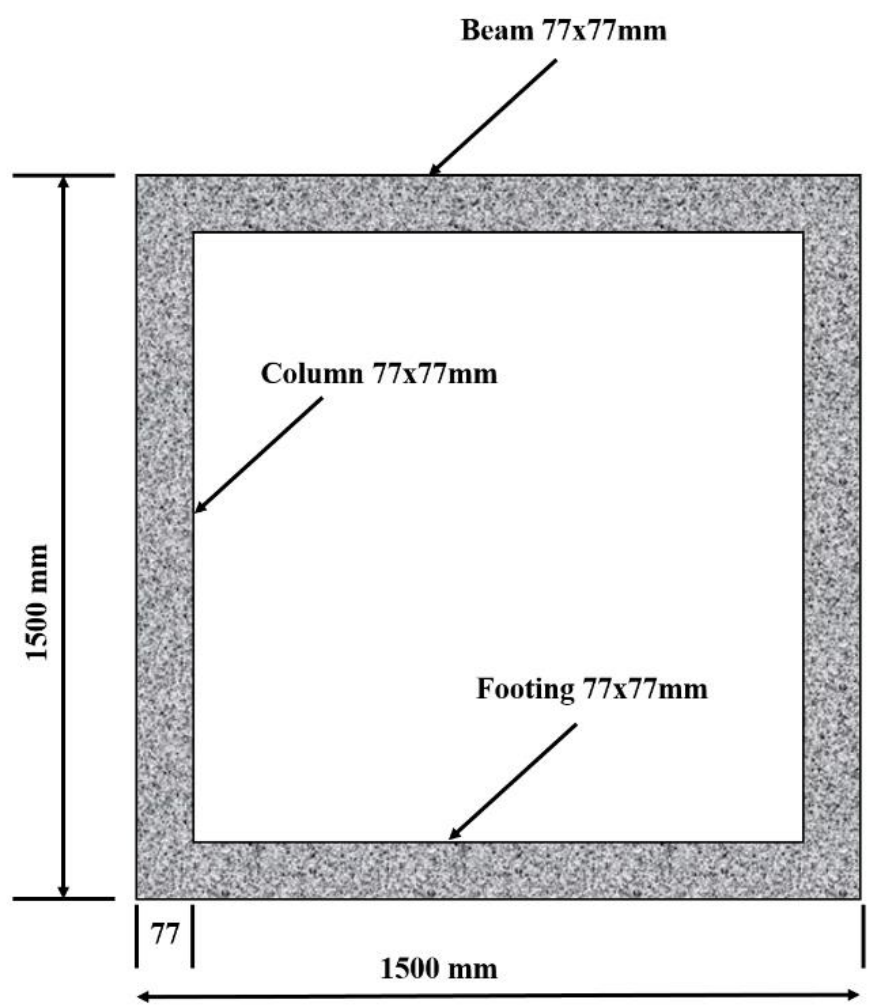

Fig. (12). Bare RC frame model [41]. 
Table 4. Dimensions of the numerical model.

\begin{tabular}{|c|c|c|c|c|}
\hline No. & Scale Factor & Member & Prototype (mm) & Our Model (mm) \\
\hline 1 & $1 / 3$ & Length of beam & 4500 & 1500 \\
\hline 2 & $1 / 3$ & Depth of beam & 200 & 77 \\
\hline 3 & $1 / 3$ & Width of beam & 200 & 77 \\
\hline 4 & $1 / 3$ & Height of column & 4500 & 1500 \\
\hline 5 & $1 / 3$ & Depth of column & 300 & 77 \\
\hline 6 & $1 / 3$ & Width of column & 200 & 77 \\
\hline
\end{tabular}

Table 5. Reinforcement details of the prototype.

\begin{tabular}{|c|c|c|}
\hline $\begin{array}{c}\text { Element } \\
\text { Type }\end{array}$ & \multicolumn{2}{|c|}{ Reinforcement Details } \\
\hline \multirow{3}{*}{ Beam } & Tension Rebar & $3 \Phi 12$ \\
\cline { 2 - 3 } & Compression Rebar & $3 \Phi 12$ \\
\cline { 2 - 3 } & Shear Reinforcement & $\Phi 8 @ 120 \mathrm{~mm} \mathrm{c} / \mathrm{c}$ \\
\hline \multirow{2}{*}{ Column } & Longitudinal Reinforcement & $4 \Phi 12$ \\
\cline { 2 - 3 } & Transverse Reinforcement & $\Phi 8 @ 200 \mathrm{~mm} \mathrm{c} / \mathrm{c}$ \\
\hline
\end{tabular}

\subsection{Results of the Numerical Simulation}

The force $v s$. displacement hysteresis curves for $0 \mathrm{~A}$ and $3 \mathrm{~A}$ currents under different earthquake motions are plotted in Fig. (13 a-d). The responses of damper force $v s$. time and damper displacement $v s$. time are plotted in Figs. (14 and 15), respectively. The Frame displacement response histories without MR damper, with $0 \mathrm{~A}$ and $3 \mathrm{~A}$ currents under four different earthquakes motions, are illustrated in Fig. (16). The numerical simulation summary is given in Table $\mathbf{6}$.

The numerical simulation results indicated that the proposed device has a superior performance in dissipating the seismic vibrations. Based on the results depicted in Figs.
(14-16) and Table 6, the proposed MR damper has a good capability in reducing the structure's deformations. It will lead to a better vibration control mechanism. The average percentage of reduction in lateral deformations is more than $90 \%$ compared to the reference bare model without any damping devices. On the other hand, a significant increase in damping force is observed when the proposed device is under $3 \mathrm{~A}$ current condition. The average increment at the device level is around $900 \%$, while at the structure's level it is around $250 \%$, which proves that the new semi-active device has improved performance as compared to those of passive and constant control devices.
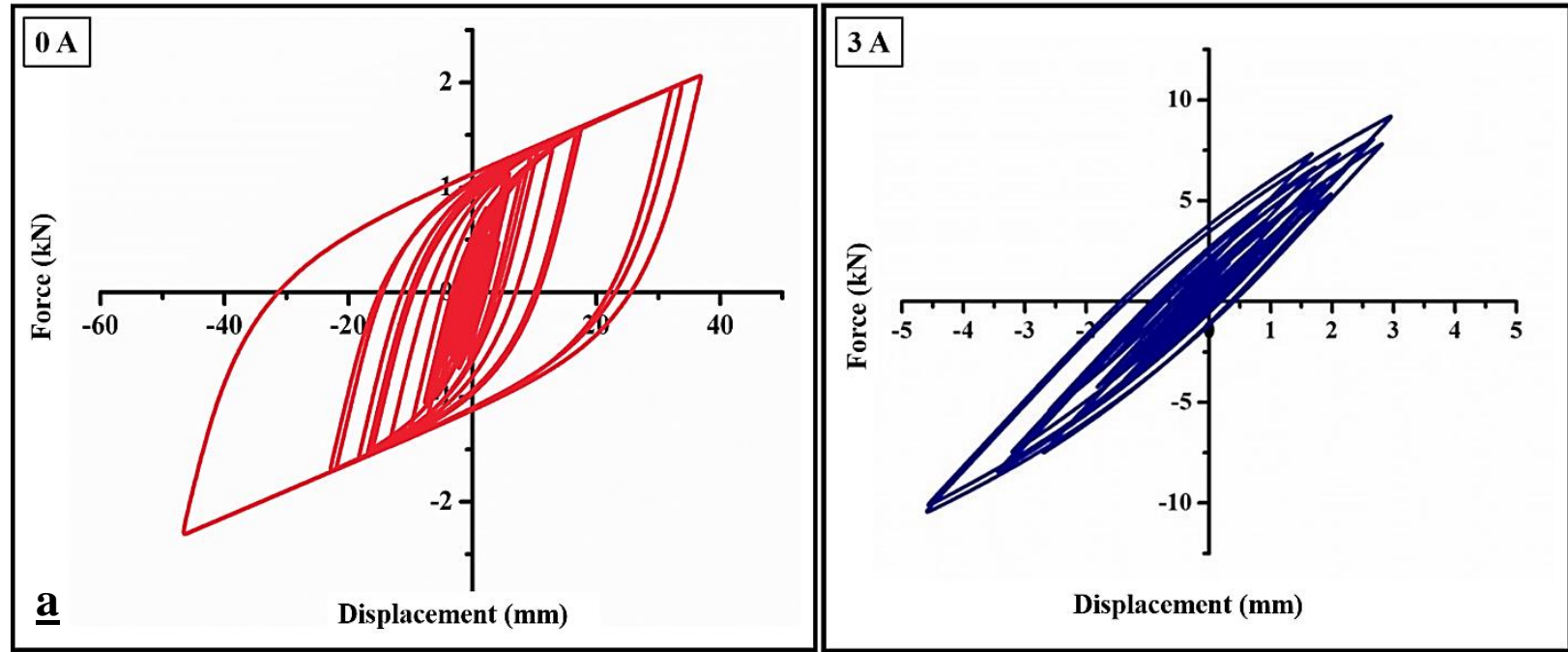

Fig. 13 contd..... 

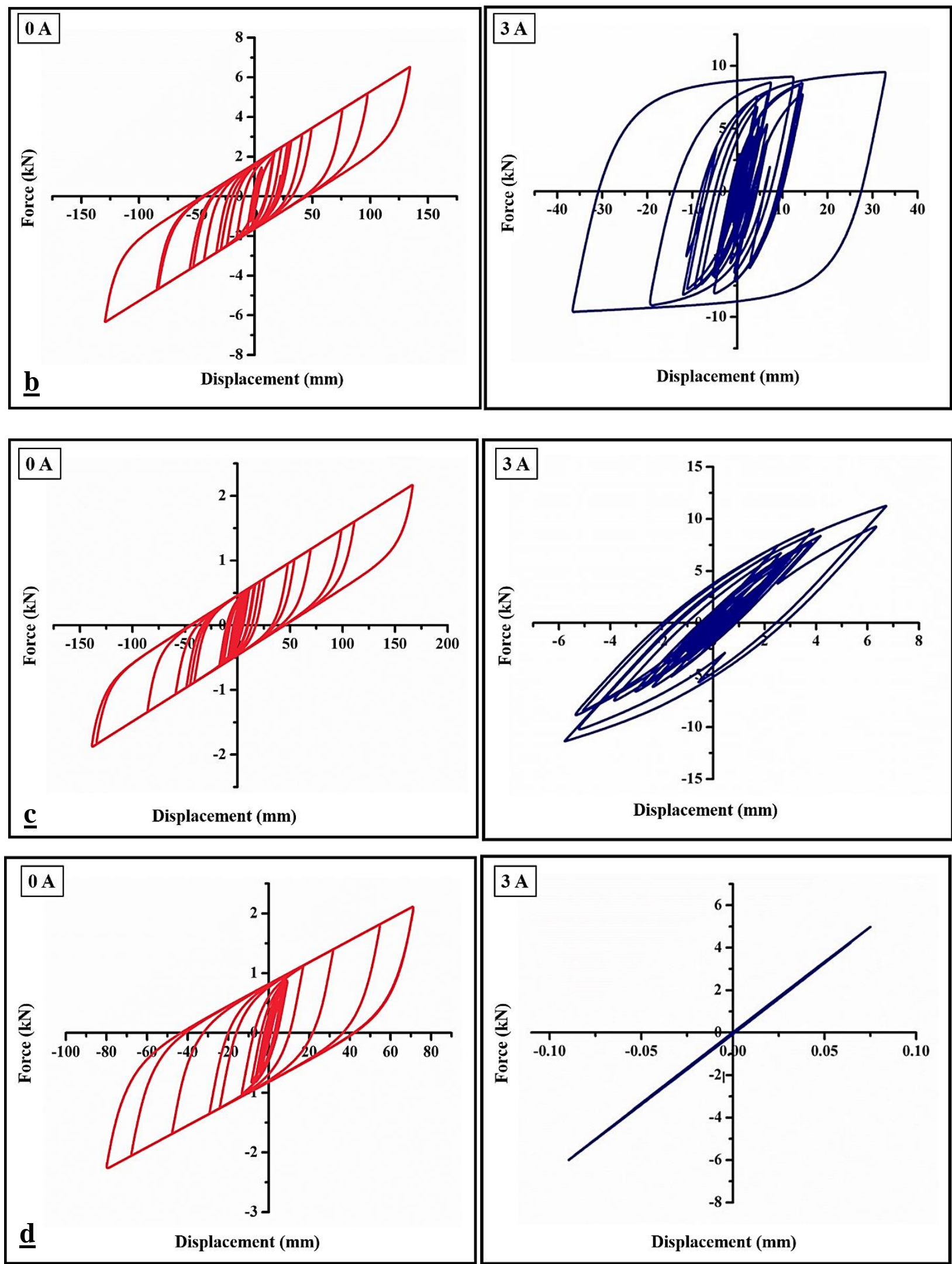

Fig. (13). Numerical simulation results of damping force $v$ s. displacement a) El Centro b) Northridge c) Petrolia d) Loma Prieta. 

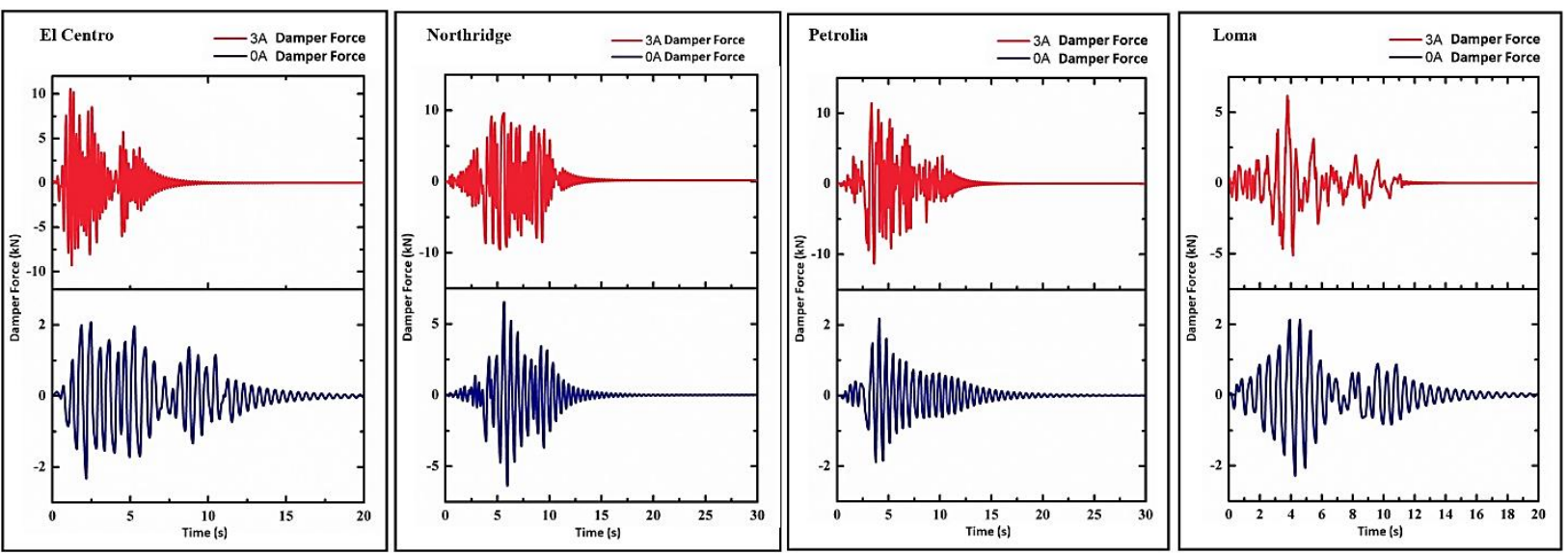

Fig. (14). Damper force vs. time (Numerical simulation results).
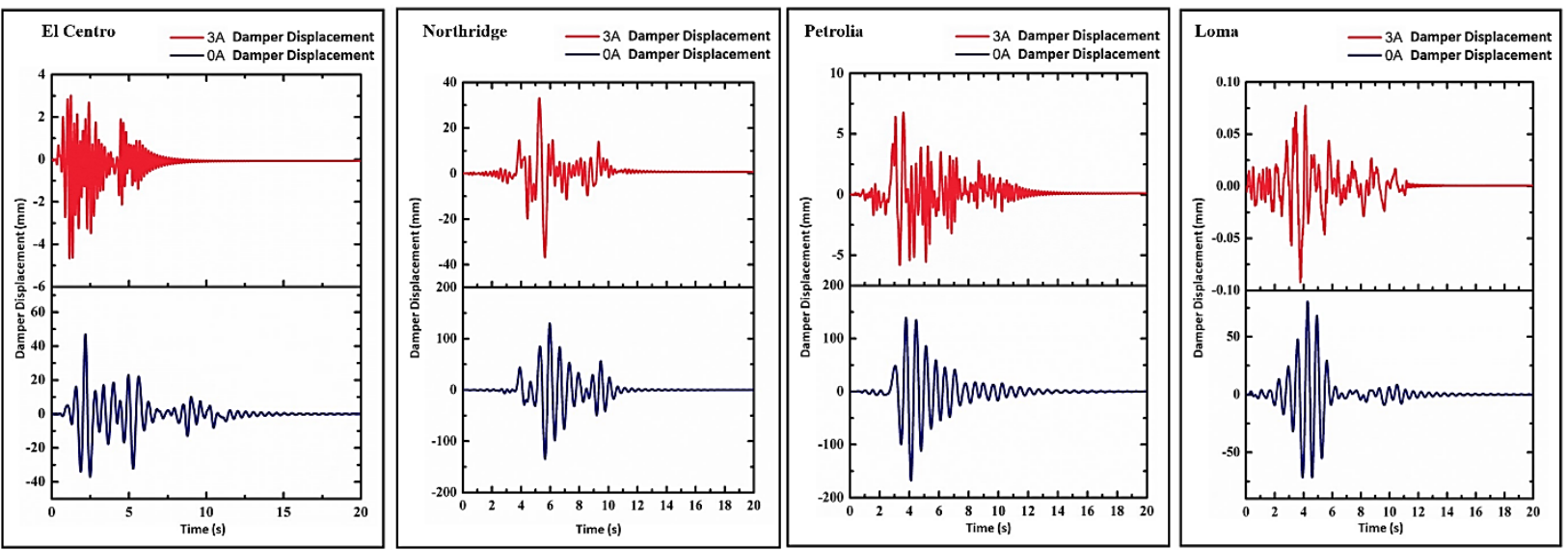

Fig. (15). Damper displacement vs. time (Numerical simulation results).

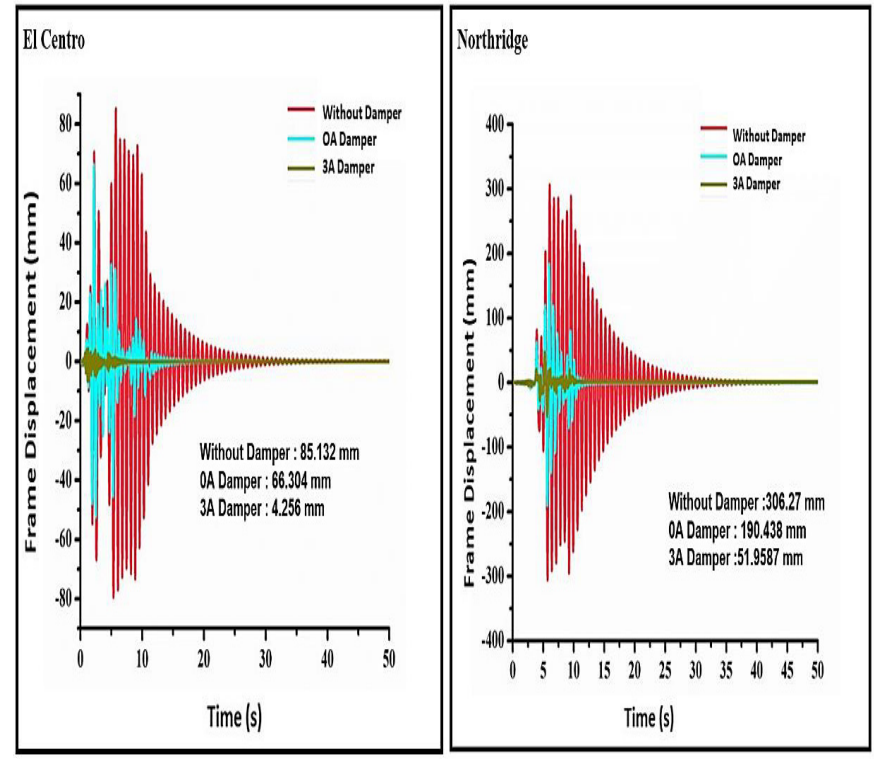

Fig. 16 contd..... 

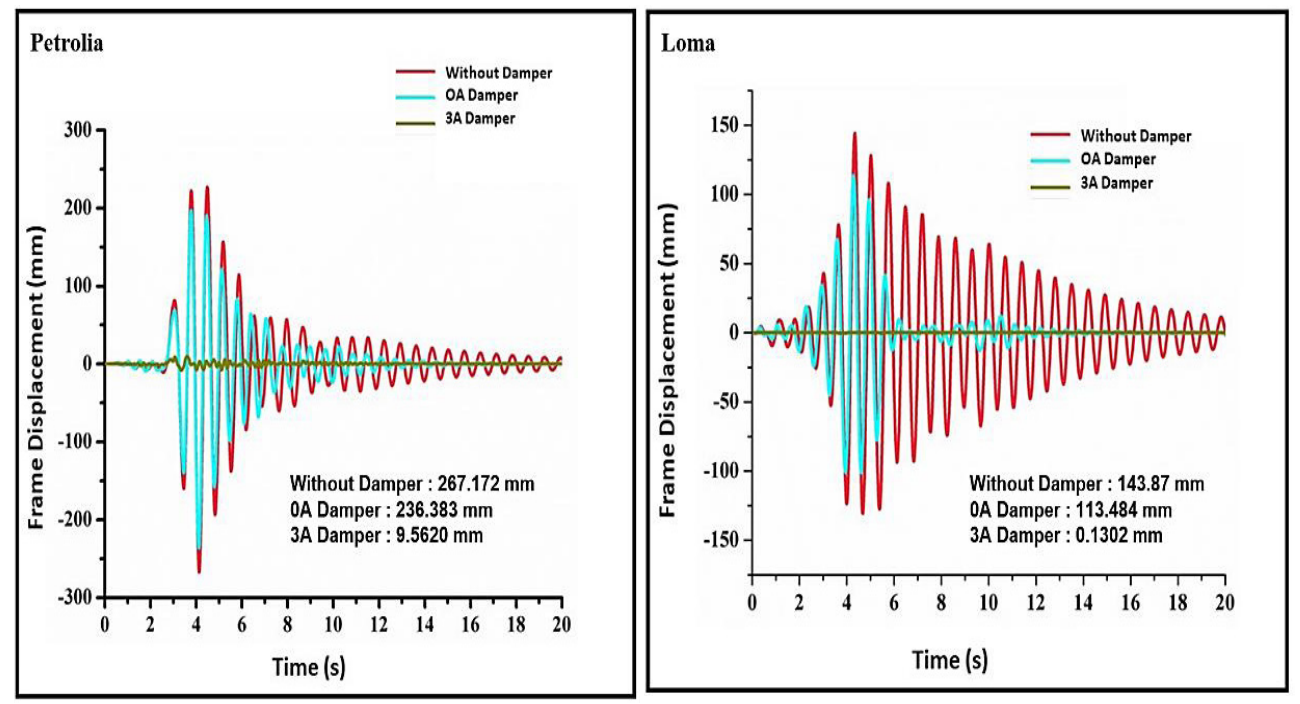

Fig. (16). Frame displacement response histories under the considered earthquakes (Numerical simulation results).

Table 6. Numerical results (Structure level).

\begin{tabular}{|c|c|c|c|c|c|c|c|}
\hline \multirow[t]{2}{*}{ Earthquake } & \multicolumn{3}{|c|}{ Maximum Displacement (mm) } & \multicolumn{2}{|c|}{$\begin{array}{c}\text { Maximum Damping Force } \\
(\mathrm{kN})\end{array}$} & \multirow{2}{*}{\begin{tabular}{|c|} 
\% Reduction in Displacement \\
$0 \mathrm{~A}$ to $3 \mathrm{~A}$ \\
\end{tabular}} & \multirow{2}{*}{$\begin{array}{c}\text { \% Increase in Damping } \\
\text { Force }\end{array}$} \\
\hline & Without MR Damper & $0 \mathrm{~A}$ & $3 \mathrm{~A}$ & $0 \mathrm{~A}$ & $3 \mathrm{~A}$ & & \\
\hline El Centro & 85.13 & 66.30 & 6.58 & 2.21 & 10.1 & 90.07 & 357.01 \\
\hline Northridge & 306.27 & 190.43 & 51.95 & 5.3 & 9.9 & 72.71 & 86.79 \\
\hline Petrolia & 267.17 & 236.38 & 9.56 & 2.05 & 10.1 & 95.95 & 392.68 \\
\hline Loma Prieta & 143.87 & 113.48 & 0.1302 & 2.2 & 5.3 & 99.88 & 140.9 \\
\hline Average & 200.61 & 151.64 & 17.06 & 2.94 & 8.85 & 89.65 & 244.34 \\
\hline
\end{tabular}

\section{CONCLUSION}

In the current study, a smart semi-active control strategy was proposed and evaluated through both experimental and numerical simulations. The proposed device is an MR damper fabricated using mild steel consists of 9 electromagnetic coils and 10 piston poles which produces more shear forces in the flow of the MR fluid. The magnetic flux density of the coil is 2.15 Tesla at $3 \mathrm{~A}$ current and 8.5 Volts. Investigations have been carried out at both local and global levels. The local investigation has been done through a real scale experiment in the laboratory. The results indicated that the proposed semiactive device has a broad adjustable damping force range under a magnetic field. It was shown that the damping coefficient increases significantly as the electric current increases, while decreases with seismic excitation amplitude. To monitor the performance of the proposed device on a global level, a 1/3 scale RC frame was simulated in the OpenSees nonlinear platform. The behavior of the proposed device under electric current cannot be treated as a viscous damper, hence a more sophisticated model should be used. To this aim, the BoucWen model has been implemented in numerical simulations. The response of the scaled-down single-story RC frame has an average lateral displacement reduction of $90 \%$ under four major seismic events, whilst the damping force has increased up to $244 \%$ on average.
As a conclusion, it is demonstrated through experimental and analytical investigations that the proposed semi-active damping device is superior over conventional control devices and can be considered as an economical and smart alternative to improve the seismic resilience of building structures in earthquake-prone areas. A more detailed investigation using a shake table is recommended to be carried out for future studies.

\section{CONSENT FOR PUBLICATION}

Not applicable

\section{AVAILABILITY OF DATA AND MATERIALS}

Implementation of the numerical part of this study was undertaken using OpenSees. All developed codes and models supporting the findings of this study are available from the corresponding author upon reasonable request.

\section{FUNDING}

The study is financially supported by the Department of Science and Technology, Karunya Institute of Technology and Sciences, India (Grant No: DST/TSG/STS/2015/30-G).

\section{CONFLICT OF INTEREST}

The authors declare no conflict of interest, financial or otherwise. 


\section{ACKNOWLEDGEMENTS}

The authors thankfully acknowledge the financial support from the Department of Science and Technology, India.

\section{REFERENCES}

[1] S.J. Dyke, B.F. Spencer Jr, M.K. Sain, and J.D. Carlson, "Modeling and control of magnetorheological dampers for seismic response reduction", Smart Mater. Struct., vol. 5, pp. 565-575, 1996. [http://dx.doi.org/10.1088/0964-1726/5/5/006]

[2] M.K. Bhardwaj, and T.K. Datta, "Semiactive Fuzzy Control of the Seismic Response of Building Frames", J. Struct. Eng., vol. 132, no. 5, pp. 791-799, 2006

[http://dx.doi.org/10.1061/(ASCE)0733-9445(2006)132:5(791)]

[3] B.F. Spencer Jr, S.J. Dyke, M.K. Sain, and J.D. Carlson, "Phenomenological Model for Magnetorheological Damper", J. Eng. Mech., vol. 123 , no. 3 , pp. $230-238,1997$.

[http://dx.doi.org/10.1061/(ASCE)0733-9399(1997)123:3(230)]

[4] J.D. Carlson, D.M. Catanzarite, and K.A. St Clair, "Commercial magneto-rheological fluid devices Proc. $5^{\text {th }}$ Int. Conf. on ER Fluids MR Fluids and Associated Technology", (University of Sheffield, UK), 1996.

[5] J D Carlson, and K D Weiss, "A growing attraction to magnetic fluids", Mach. Des, pp. 61-66, 1994.

[6] J.D. Carlson, The promise of controllable fluids Proc. Actuator 94, Bremen: AXON Technologies Consult GmbH, 1994, pp. 266-70.Borgmann. H, and Lenz. K,

[7] R. Stanway, J.L. Sproston, and A.K. El-Wahed, "Applications of electro-rheological fluids in vibration control: A survey", Smart Mater. Struct., vol. 5, pp. 464-482, 1996. [http://dx.doi.org/10.1088/0964-1726/5/4/011]

[8] M. Bozorgvar, and S.M. Zahrai, "Semi-active seismic control of buildings using MR damper and adaptive neural-fuzzy intelligent controller optimized with genetic algorithm", J. Vib. Control, vol. 25, no. 2, pp. 273-285, 2019 [http://dx.doi.org/10.1177/1077546318774502

[9] M. Abdeddaim, A. Ounis, S.D. Bharti, and M.K. Shrimali, "Seismic Retrofitting Using the Concept of Coupling Two Adjacent Buildings", In: Rec. Adv. Struct. Eng., vol. 2. 2019, pp. 355-363.

[10] V. Bhaiya, S.D. Bharti, M.K. Shrimali, and T.K. Datta, "Performance of semi-actively controlled building frame using $\mathrm{mr}$ damper for nearfield earthquakes", In: Rec. Adv. Struct. Eng., vol. 2. 2019, pp. 397-407.

[11] C.B. Priya, and N. Gopalakrishnan, "Experimental investigations of the effect of temperature on the characteristics of MR damper", In: Rec. Adv. Struct. Eng., vol. 2. 2019, pp. 435-443.

[12] B.F. Spencer Jr, and M.K. Sain, "Controlling buildings: A new frontier in feedback", IEEE Contr. Syst. Mag., vol. 17,pp. 19-35, 1997. [http://dx.doi.org/10.1109/37.642972]

[13] M.D. Symans, and M.C. Constantinou, "Semiactive control systems for seismic protection of structures: A state-of-the-art review", Eng. Struct., vol. 21, pp. 469-487, 1999. [http://dx.doi.org/10.1016/S0141-0296(97)00225-3]

[14] J.D. Carlson, and B.F. Spencer Jr, "Magneto-rheological fluid dampers for semiactive seismic control", Proc. $3^{\text {rd }}$ Int. Conf. on Motion and Vibration Control, vol. vol III, 1996pp. 35-40 Chiba, Japan

[15] B.F. Spencer Jr, G. Yang, J.D. Carlson, and M.K. Sain, "Smart dampers for seismic protection of structures: A full-scale study", Proc. 2nd World Conf. on Struct. Control, vol. 1, pp. 417-426, 1999.

[16] M.J. Chrzan, and J.D. Carlson, "MR fluid sponge devices and their use in vibration control of washing machines", Proc. SPIE, Smart Structures and Materials, pp. 370-378, 2001.

[http://dx.doi.org/10.1117/12.432719]

[17] M. Thomas, A.A. Lakis, and S. Sassi, "Adverse health effects of longterm whole-body random vibration exposure", Rec. Res. Develop. Sound. Vibration, vol. 2, pp. 55-73, 2004.

[18] C. Daniel, G. Hemalatha, A. Magdalene, D. Tensing, and S.S. Manoharan, "Magnetorheological damper for performance enhancement against seismic forces", International Congress and Exhibition Sustainable Civil Infrastructures: Innovative Infrastructure Geotechnology, pp. 104-117, 2017.

[19] S. J. Dyke, B. F. Spencer Jr, M. K. Sain, and J. D. Carlson, "An experimental study of MR dampers for seismic protection", Smart. Mater. Structures, vol. 7:5, p. 693, 1998. [http://dx.doi.org/10.1088/0964-1726/7/5/012]
[20] S.J. Dyke, B.F. Spencer Jr, M.K. Sain, and J.D. Carlson, "Seismic response reduction using magnetorheological dampers", IFAC Proceedings, vol. 29:1, 1996pp. 5530-5535

[http://dx.doi.org/10.1016/S1474-6670(17)58562-6]

[21] S.D. Bharti, S.M. Dumne, and M.K. Shrimali, "Seismic response analysis of adjacent buildings connected with MR dampers", Eng. Struct., vol. 32, no. 8, pp. 2122-2133, 2010 [http://dx.doi.org/10.1016/j.engstruct.2010.03.015]

[22] F. Gordaninejad, X. Wang, G. Hitchcock, K. Bangrakulur, S. Ruan, and M. Siino, "Modular high-force seismic magneto-rheological fluid damper", J. Struct. Eng., vol. 136, no. 2, pp. 135-143, 2010. [http://dx.doi.org/10.1061/(ASCE)0733-9445(2010)136:2(135)]

[23] M.G. Yang, Z.Q. Chen, and X.G. Hua, "An experimental study on using MR damper to mitigate longitudinal seismic response of a suspension bridge", Soil. Dyn. Earthquake Eng., vol. 31, no. 8, pp. 1171-1181, 2011.

[http://dx.doi.org/10.1016/j.soildyn.2011.04.006]

[24] N. Caterino, M. Spizzuoco, and A. Occhiuzzi, "Understanding and modelling the physical behaviour of magnetorheological dampers for seismic structural control", Smart. Mater. Structures, vol. 20:6, p. 065013, 2011.

[http://dx.doi.org/10.1088/0964-1726/20/6/065013]

[25] L. Wang, W. Shi, Y. Zhou, and Q. Zhang, "Semi-active eddy current pendulum tuned mass damper with variable frequency and damping", Smart Struct. Syst., vol. 25, no. 1, pp. 65-80, 2020.

[26] L. Wang, W. Shi, X. Li, Q. Zhang, and Y. Zhou, "An adaptive-passive retuning device for a pendulum tuned mass damper considering mass uncertainty and optimum frequency", Struct. Contr. Health. Monitoring, vol. 26:7, 2019.e2377

[27] Y. Ding, L. Zhang, H. T. Zhu, and Z. X. Li, "A new magnetorheological damper for seismic control", Smart. Mater. Structures, vol. 22:11, p. 115003, 2013.

[http://dx.doi.org/10.1088/0964-1726/22/11/115003]

[28] D. Das, T.K. Datta, and A. Madan, "Semiactive fuzzy control of the seismic response of building frames with MR dampers", Earthquake Eng. Struct. Dynam., vol. 41, no. 1, pp. 99-118, 2012 [http://dx.doi.org/10.1002/eqe.1120]

[29] M.G. Yang, C.Y. Li, and Z.Q. Chen, "A new simple non-linear hysteretic model for MR damper and verification of seismic response reduction experiment", Eng. Struct., vol. 52, pp. 434-445, 2013.

[http://dx.doi.org/10.1016/j.engstruct.2013.03.006]

[30] Y. Chae, J.M. Ricles, and R. Sause, "Modeling of a large-scale magneto-rheological damper for seismic hazard mitigation. Part I: Passive mode", Earthquake Eng. Struct. Dynam., vol. 42, no. 5, pp. 669-685, 2013.

[http://dx.doi.org/10.1002/eqe.2237]

[31] "Semi-active control of structures using neuro-predictive algorithm for MR dampers", Structural Control and Health Monitoring, vol. 17, no. 3, pp. $237-253,2010$

[32] A. Guo, Z. Li, H. Li, and J. Ou, "Experimental and analytical study on pounding reduction of base-isolated highway bridges using MR dampers", Earthquake Eng. Struct. Dynam., vol. 38, no. 11, pp. 1307-1333, 2009

[http://dx.doi.org/10.1002/eqe.903]

[33] S. Akcelyan, D.G. Lignos, and T. Hikino, "Adaptive numerical method algorithms for nonlinear viscous and bilinear oil damper models subjected to dynamic loading", Soil. Dyn. Earthquake Eng., vol. 113 , pp. 488-502, 2018.

[http://dx.doi.org/10.1016/j.soildyn.2018.06.021]

[34] S. Akcelyan, D. G. Lignos, T. Hikino, and M. Nakashima, "Evaluation of simplified and state-of-the-art analysis procedures for steel frame buildings equipped with supplemental damping devices based on EDefense full-scale shake table tests", J. Struct. Engineering, vol. 142:6, p. $04016024,2016$. [http://dx.doi.org/10.1061/(ASCE)ST.1943-541X.0001474]

[35] MRF 132 DG Magnetorheological Fluid, Technical Data,

[36] M.D. Christie, S. Sun, L. Deng, D.H. Ning, H. Du, S.W. Zhang, and W.H. Li, "A variable resonance magnetorheological-fluid-based pendulum tuned mass damper for seismic vibration suppression", Mech. Syst. Signal Process., vol. 116, pp. 530-544, 2019. [http://dx.doi.org/10.1016/j.ymssp.2018.07.007]

[37] O.A. Al-Fahdawi, L.R. Barroso, and R.W. Soares, "Semi-active adaptive control for enhancing the seismic performance of nonlinear coupled buildings with smooth hysteretic behavior", Eng. Struct., vol. 191, pp. 536-548, 2019.

[http://dx.doi.org/10.1016/j.engstruct.2019.04.078]

[38] V. Bhaiya, S.D. Bharti, M.K. Shrimali, and T.K. Datta, "Hybrid 
seismic control of buildings using tuned mass and magnetorheological dampers", Proceedings of the Institution of Civil Engineers-Structures and Buildings, 2019pp. 1-17

[http://dx.doi.org/10.1680/jstbu.18.00090]

[39] C. Bharathi Priya, and N. Gopalakrishnan, "Seismic retrofit of reinforced concrete structures using magnetorheological mass driver: Evolving a design methodology", Struct. Contr. Health Monit., p. 2353, 2019.

[http://dx.doi.org/10.1002/stc.2353]

[40] R. Dey, and P. Saha, "Seismic response control of smart base-isolated benchmark building using hybrid control strategy (viscous fluid damper with mr damper)", In: Rec. Adv. Struct. Eng., vol. 2. 2019, pp.
365-374

41] J.S. Joseph, H. Gladston, and V. Vellapandi, "Development of link column frame system for seismic resistance of reinforced concrete structures", Adv. Civ. Eng. Mater., vol. 7, no. 3, pp. 523-546, 2018. [http://dx.doi.org/10.1520/ACEM20170106]

[42] Y.K. Wen, "Method of random vibration of hysteretic systems", $J$ Eng. Mech. Div., vol. 102, no. 2, pp. 249-263, 1976.

[43] J.J. Shelton, G. Hemalatha, and R. Venkatesh, "Experimental investigation on link column frame system for reinforced concrete structures", International Congress and Exhibition Sustainable Civil Infrastructures: Innovative Infrastructure Geotechnology, pp. 446-459, 2017.

\section{(C) 2020 Cruze et al.}

This is an open access article distributed under the terms of the Creative Commons Attribution 4.0 International Public License (CC-BY 4.0), a copy of which is available at: https://creativecommons.org/licenses/by/4.0/legalcode. This license permits unrestricted use, distribution, and reproduction in any medium, provided the original author and source are credited. 